\title{
Dietary antioxidants and DNA damage in patients on long-term acid- suppression therapy: a randomized controlled study
}

\author{
K. L. M. White ${ }^{1}$, D. M. Chalmers ${ }^{2}$, I. G. Martin ${ }^{2}$, S. M. Everett ${ }^{2}$, P. M. Neville ${ }^{2}$, G. Naylor ${ }^{2}$, \\ A. E. Sutcliffe ${ }^{1}$, M. F. Dixon ${ }^{2}$, P. C. Turner ${ }^{1}$ and C. J. Schorah ${ }^{1}$ \\ ${ }^{1}$ Molecular Epidemiology Unit, Epidemiology and Health Services Research, University of Leeds, Leeds LS2 9JT, UK \\ ${ }^{2}$ The Centre for Digestive Diseases, The General Infirmary at Leeds, Great George Street, Leeds LS1 3EX, UK
}

(Received 20 September 2001 - Revised 13 March 2002 - Accepted 8 April 2002)

\begin{abstract}
Free radicals and reactive species produced in vivo can trigger cell damage and DNA modifications resulting in carcinogenesis. Dietary antioxidants trap these species limiting their damage. The present study evaluated the role of vitamins $\mathrm{C}$ and $\mathrm{E}$ in the prevention of potentially premalignant modifications to DNA in the human stomach by supplementing patients who, because of hypochlorhydria and possible depletion of gastric antioxidants, could be at increased risk of gastric cancer. Patients undergoing surveillance for Barrett's oesophagus ( $n$ 100), on long-term proton pump inhibitors were randomized into two groups: vitamin C (500 mg twice/d) and vitamin E (100 mg twice/d) for 12 weeks (the supplemented group) or placebo. Those attending for subsequent endoscopy had gastric juice, plasma and mucosal measurements of vitamin levels and markers of DNA damage. Seventy-two patients completed the study. Plasma ascorbic acid, total vitamin $\mathrm{C}$ and vitamin $\mathrm{E}$ were elevated in the supplemented group consistent with compliance. Gastric juice ascorbic acid and total vitamin $\mathrm{C}$ levels were raised significantly in the supplemented group $(P=0 \cdot 01)$ but supplementation had no effect on the mucosal level of this vitamin. However, gastric juice ascorbic acid and total vitamin $\mathrm{C}$ were within normal ranges in the unsupplemented group. Mucosal malondialdehyde, chemiluminescence and DNA damage levels in the comet assay were unaffected by vitamin supplementation. In conclusion, supplementation does not affect DNA damage in this group of patients. This is probably because long-term inhibition of the gastric proton pump alone does not affect gastric juice ascorbate and therefore does not increase the theoretical risk of gastric cancer because of antioxidant depletion.
\end{abstract}

Antioxidants: Ascorbic acid: Gastric juice pH: DNA damage

It is widely accepted that free radicals and reactive species can be produced in human tissues, and that their release increases as a result of pathological processes (Halliwell, 1994). These species are highly reactive towards molecules in their immediate vicinity and can trigger chain reactions leading to widespread cell damage (Lunec, 1990). Importantly, they promote modifications to DNA, which can produce mutations and initiate carcinogenesis (Dizdaroglu, 1993; Guyton \& Kensler, 1993). In healthy tissue and biological fluids there is evidence of a reservoir of antioxidant micronutrients, present in both the aqueous and the lipid phases, which can effectively trap reactive species and free radicals, and limit the damage they do. Central to this role are vitamins $\mathrm{C}$ and $\mathrm{E}$, which not only work in aqueous and lipid environments respectively but in combination are both synergistic and catalytic (Schorah, 1995). It has been shown that gastric mucosa contains a high concentration of ascorbate with secretion of the vitamin into the gastric juice (Waring et al. 1996). Conditions such as Helicobacter pylori associated gastritis, gastric atrophy and hypochlorhydria, the background on which gastric cancer develops, reduce and eventually eliminate this secretion (Sobala et al. 1989; Schorah et al. 1991). In addition, the atrophic hypochlorhydric stomach is an ideal environment for the generation of carcinogenic reactive species, such as gastric juice nitrocarcinogens, and mucosal oxygen free radicals and lipid degradation products are formed as part of the inflammatory response

\footnotetext{
Abbreviations: DMEM, Dulbecco's modified eagle medium; DTT, dithiothreitol; MDA, malondialdehyde; PPI, proton pump inhibitor; TAP, total antioxidant potential; TBA, thiobarbituric acid.

* Corresponding author: K. L. M. White, fax +44 113233 6603, email medklmw@leeds.ac.uk
} 
(Kyrtopoulos, 1989; Correa, 1992). Ascorbic acid can efficiently trap or quench these reactive species (Schorah, 1995; Drake et al. 1996) and is supported in this role by vitamin E. Thus it is of major interest to investigate if these dietary antioxidants can ameliorate those factors associated with an increased risk of carcinogenesis in the human stomach. The present study was designed to examine this question. We have shown that the low level of juice ascorbate found in the diseased stomach can be elevated by both supplementation (500 mg twice/d) and $H$. pylori eradication (Sobala et al. 1993; Waring et al. 1996). However, such eradication is accompanied by other changes in addition to the increase in ascorbic acid, such as decreased mucosal infiltration by inflammatory cells, decreased free radical generation and decreased $\mathrm{pH}$. In this situation it is therefore impossible to assess the individual contribution that the improved gastric antioxidant status makes to the risk of DNA damage independent of these other factors. With this in mind, we set out to study subjects on longterm proton pump inhibitor (PPI) therapy who may be considered to be at increased risk of DNA damage because of hypochlorhydria which in turn leads to low levels of gastric juice ascorbate, both features being associated with an increased risk of gastric cancer (Schorah et al. 1991). We assessed changes in putative markers of DNA damage in gastric tissue following supplementation with vitamins $\mathrm{C}$ and $\mathrm{E}$. These were the concentration of malondialdehyde (MDA), a measure of reactive species damage to lipids, and itself a potential genotoxin (Fang et al. 1996), chemiluminescence levels, which measure the rate of free radical generation (Drake et al. 1995, 1996) and the comet test to assess DNA damage (Everett et al. 2000). Plasma vitamin $C$ and $E$ were measured to assess patient compliance and total antioxidant potential measured to assess general antioxidant reserves (Whitehead et al. 1992). Gastric juice ascorbic acid and total vitamin C (ascorbic acid plus dehydroascorbic acid) were measured in order to assess if antioxidant supplementation had led to recovery of these components in gastric juice in subjects who, by virtue of PPI treatment, would be suspected of having very low levels of gastric juice ascorbate.

\section{Methods}

One hundred subjects were randomly recruited from patients with Barrett's oesophagus on long-term $(>12$ months) PPI treatment attending for surveillance endoscopy at Leeds General Infirmary. Local ethics committee permission was granted. Exclusion criteria included pregnancy or lactation, previous gastric surgery, serious cardiovascular, respiratory, renal or neurological diseases, history of alcohol or drug abuse or use of non-steroidal antiinflammatory drugs. Each subject was initially contacted at home by telephone before endoscopy and invited to attend to discuss the project with a doctor. Informed consent was obtained in all cases. Details about smoking, alcohol intake, drug use and vitamin $\mathrm{C}$ intake were recorded. The vitamin $\mathrm{C}$ intake was estimated using a simple dietary questionnaire previously used within our group. Subjects were asked how many times per week they ate potatoes, green leafy vegetables, and fresh citrus fruits and drank fresh orange or grapefruit juice.

The present study was a randomized, double-blind trial. Subjects were randomized by pharmacy to either $500 \mathrm{mg}$ vitamin $\mathrm{C}$ plus $100 \mathrm{mg}$ vitamin $\mathrm{E}$, twice daily for 12 weeks, or placebos twice daily for 12 weeks. Subjects underwent endoscopy during week 12 and were requested not to take these tablets on that day. For comparison, controls were selected from two trials, both previously published from our group (Everett et al. 2001, 2002). The following criteria were applied to these control subjects: (i) both gastric antral and corpus histology were normal; (ii) negative for $H$. pylori; (iii) not taking PPI or $\mathrm{H}_{2}$ receptor antagonist to provide acid suppression.

Samples taken included $10 \mathrm{ml}$ of blood into a lithium heparin tube, $2 \mathrm{ml}$ of gastric juice aspirated via a sterile canula inserted down the biopsy channel, ten antral and three corpus biopsies.

\section{$p H$}

The $\mathrm{pH}$ of gastric juice was estimated immediately using universal $\mathrm{pH}$ paper.

\section{Histology}

Two antral and two corpus biopsies were fixed in $10 \%(\mathrm{v} / \mathrm{v})$ formalin, sequential $3 \mu \mathrm{m}$ sections were cut and stained with haematoxylin and eosin and modified Giemsa stains. They were assessed for presence of gastritis and $H$. pylori infection.

\section{Malondialdehyde}

Two antral biopsies from each subject were analysed using a modification of the method used by Yagi (1976). Biopsies were immediately snap-frozen in liquid $\mathrm{N}_{2}$ and stored at $-70^{\circ} \mathrm{C}$ until assayed. Biopsies were blotted until all the moisture was removed then weighed and added to $4 \mathrm{ml}$ water. Thiobarbituric acid (TBA) solution (1 ml; 0.046 M) made in distilled water-glacial acetic acid $(1: 1, \mathrm{v} / \mathrm{v})$ was added. A range of MDA standards were prepared in the same way $(0-1000 \mathrm{pmol})$. All solutions were heated to $100^{\circ} \mathrm{C}$ for $60 \mathrm{~min}$. After cooling for $20 \mathrm{~min}, 5 \mathrm{ml}$ butan-1ol was added to each tube and mixed for $30 \mathrm{~s}$. The tubes were centrifuged at $1100 \mathrm{~g}$ for $10 \mathrm{~min}$ at room temperature. Fluorescence of the butanol layer was measured using excitation wavelength $515 \mathrm{~nm}$ and emission wavelength $555 \mathrm{~nm}$. The compounds formed were TBA-MDA products and values were expressed as $\mu \mathrm{mol}$ TBA-related species $/ \mathrm{kg}$ wet weight of tissue. The mean of the two results was used.

\section{Luminol-enhanced chemiluminescence}

Two antral biopsies from each subject were immediately transferred into PBS and assayed within $3 \mathrm{~h}$ using a modification of the method used by Davies et al. (1992). Each biopsy was added to a precounted scintillation vial containing $1 \mathrm{ml}$ of $75 \mu \mathrm{mol}$ luminol in dimethyl sulfoxide and counted for $5 \mathrm{~min}$ in a liquid scintillation counter set in 
the 'out of coincidence' mode. The biopsy was then blotted and weighed. Values were expressed as counts/min per mg wet weight of tissue. The mean of two results was used.

\section{Comet assay}

Two antral biopsies from each subject were immediately added to Dulbecco's modified eagle medium (DMEM), containing $10 \%(\mathrm{v} / \mathrm{v})$ dimethyl sulfoxide. They were stored overnight at $4^{\circ} \mathrm{C}$ and assayed at approximately $20 \mathrm{~h}$ after collection using Singh's method with modifications (Singh et al. 1988). Preliminary studies on method development showed that adding $10 \%$ dimethyl sulfoxide to DMEM allowed storage of biopsies at $4^{\circ} \mathrm{C}$ overnight without causing significant change in DNA damage (Everett et al. 2000).

A cell suspension was prepared using the two biopsies suspended in $800 \mu \mathrm{l}$ DMEM with $100 \mu \mathrm{l}$ of $0.1 \%(\mathrm{w} / \mathrm{v})$ pronase and $100 \mu \mathrm{l}$ of $0.03 \%(\mathrm{w} / \mathrm{v})$ collagenase, and incubated at $37^{\circ} \mathrm{C}$ for $45 \mathrm{~min}$. After incubation the biopsies were removed and the suspension spun for $5 \mathrm{~s}$ at $2400 \mathrm{~g}$. The top $600 \mu \mathrm{l}$ was removed and the cells re-suspended in the remaining $400 \mu \mathrm{l}$. Cell suspension $(60 \mu \mathrm{l})$ was added to $300 \mu \mathrm{l}$ of $1 \%$ (w/v) low melting point agarose in $\mathrm{PBS}$ (kept at $37^{\circ} \mathrm{C}$ ). Of this suspension, $162 \mu \mathrm{l}$ was put onto a slide pre-coated with $100 \mu \mathrm{l}$ of $1 \%(\mathrm{w} / \mathrm{v})$ normal melting point agarose. The suspension was covered with a coverslip to produce a block of suspended cells. Two slides were prepared for each subject. All subsequent steps were carried out in the dark to prevent u.v. light damaging the DNA. Slides were immersed in lysis buffer $(2.5 \mathrm{M} \mathrm{NaCl}, 100 \mathrm{~mm}$ sodium ethylenediaminetetra-acetic acid, $1 \%(\mathrm{w} / \mathrm{v})$ n-lauroyl sarcosine, $10 \mathrm{~mm}$ Tris $\mathrm{pH} 10$, $1 \%(\mathrm{v} / \mathrm{v})$ Triton) at $4^{\circ} \mathrm{C}$ for $60 \mathrm{~min}$ then transferred to running buffer $(300 \mathrm{~mm} \mathrm{NaOH}, 1 \mathrm{~mm}$ ethylenediaminetetraacetic acid) at $\mathrm{pH} 13$ for $20 \mathrm{~min}$, which allowed the DNA to unwind. This was followed by $15 \mathrm{~min}$ electrophoresis at $23 \mathrm{~V}$ (variable ampage). The slides were removed, carefully blotted and immersed in neutralising buffer $(400 \mathrm{~mm}$ Tris $\mathrm{pH}$ 7.5) and stained with $25 \mu \mathrm{l}$ ethidium bromide $(20 \mu \mathrm{l} / \mathrm{ml})$.

The slides were viewed using a fluorescent u.v. microscope at $\times 500$ magnification. Two hundred cells were counted and the number of normal cells and comets were recorded. A normal cell was defined as a cell with coiled DNA giving the appearance of a sphere, and a comet defined as having unwound DNA forming a tail, giving a tail length greater than half the length of the head. The results were recorded as percentage comets per subject (mean of two slides). This method of scoring has an intra-individual CV of $4.5 \%$ (Everett et al. 2000).

\section{Ascorbic acid and total vitamin $C$}

Biopsy. One antral and one corpus biopsy were snapfrozen in liquid $\mathrm{N}_{2}$ and stored at $-70^{\circ} \mathrm{C}$. After thawing the samples were blotted and weighed. They were homogenised in $600 \mu \mathrm{l}$ of $2 \%(\mathrm{w} / \mathrm{v})$ metaphosphoric acid, centrifuged at $2000 \mathrm{~g}$ for $15 \mathrm{~min}$ and the supernatant fraction analysed by HPLC using reversed phase ion pair chromatography on a C18 column with electrochemical detection at low voltage (Sobala et al. 1991; Waring et al. 1996). This gave a value for ascorbic acid. Once assayed, dithiothreitol (DTT) was added to the supernatant fraction to give a final concentration of $6 \mathrm{mg} / \mathrm{ml}$. This was incubated at $45^{\circ} \mathrm{C}$ for $120 \mathrm{~min}$ to reduce any dehydroascorbic acid to ascorbic acid, and assayed as before to give a value for total vitamin $\mathrm{C}$.

Blood and gastric juice. $500 \mu \mathrm{l}$ of gastric juice was added to two vials; one contained $6 \mathrm{mg}$ DTT. $500 \mu \mathrm{l}$ of $2 \%(\mathrm{w} / \mathrm{v})$ metaphosphoric acid containing $0.5 \%(\mathrm{w} / \mathrm{v})$ sulfamic acid was added to each vial. These were stored at $-70^{\circ} \mathrm{C}$ until assayed. Before endoscopy a blood sample was taken, spun down at $2000 \mathrm{~g}$ for $10 \mathrm{~min}$, and $500 \mu \mathrm{l}$ of plasma was added to two vials one containing $9 \mathrm{mg}$ DTT $(6 \mathrm{mg} / \mathrm{ml}$ equivalent) and $1 \mathrm{ml}$ of $2 \%(\mathrm{w} / \mathrm{v})$ metaphosphoric acid added to each vial. These were stored at $-70^{\circ} \mathrm{C}$. Once thawed the treated samples were centrifuged at $2000 \mathrm{~g}$ for $15 \mathrm{~min}$ at $4^{\circ} \mathrm{C}$. The samples without DTT were assayed immediately; those with DTT were incubated at $45^{\circ} \mathrm{C}$ for $120 \mathrm{~min}$ and then assayed. The measurements were carried out as for ascorbic acid and total vitamin $\mathrm{C}$ in biopsies.

\section{Vitamin E}

Using $200 \mu \mathrm{l}$ plasma stored at $-70^{\circ} \mathrm{C}, \alpha$-tocopherol was assayed using Thurnham's method (Thurnham et al. 1988) with minor modification (Sanderson et al. 1997). Plasma proteins were precipitated with ethanol containing tocopheryl acetate as internal standard. Hexane was added and the lipophilic tocopherol and tocopheryl acetate were extracted into the hexane layer by vigorous shaking for $2 \mathrm{~min}$ followed by centrifuging at $78 \mathrm{~g}$ for $4 \mathrm{~min}$. The upper layer was removed, dried under $\mathrm{N}_{2}$ and reconstituted in ethanol. The ethanol containing tocopherol and tocopheryl acetate were quantified by reversed phase HPLC using a C18 column and u.v. detection wavelength $292 \mathrm{~nm}$.

\section{Total antioxidant potential}

Total antioxidant potential (TAP) was measured in plasma stored at $-70^{\circ} \mathrm{C}$ using Whitehead's method (Whitehead et al. 1992) which allows quantification of the most important antioxidants in the body, namely enzymes (superoxide dismutase, catalase, glutathione and glutathione peroxidase), chain-breaking antioxidants (ascorbic acid, urate, sulfydryl groups, bilirubin, tocopherol, carotenoids) and preventative antioxidants (transferin, caeniloplasmin, heptoglobin, haemopexin).

\section{Data analysis}

As these data were skewed, non-parametric statistical analyses were used. Thus, data are presented as medians with interquartile ranges, and the Mann-Whitney $U$ test was used for unpaired comparisons. A $P$ value of $<0.05$ was taken to infer statistical significance. Data were analysed using Astute, an add-in program for Microsoft ${ }^{\circledR}$ Excel 4 and 5 (DDU Software, University of Leeds, UK). 


\section{Results}

The one hundred subjects were initially randomized. However seventeen failed to attend for endoscopy and eleven were not compliant with study medication, leaving seventytwo from whom samples were taken. The seventy-two subjects had a mean age of 63 (range 43-77) years; there were forty-two males and thirty females. Histology showed that thirty-three had normal gastric histology, twenty-eight had chemical (reactive) gastritis, and eleven had chronic inflammation, of whom two were positive for $H$. pylori. Seventeen subjects did not produce enough gastric juice for collection, possibly a side-effect of PPI therapy. We were also unable to carry out sixteen chemiluminescence tests and fifteen comet tests due to equipment failure and operator illness.

Forty-nine subjects were taking omeprazole; nine were taking $10 \mathrm{mg} / \mathrm{d}$, nineteen were taking $20 \mathrm{mg} / \mathrm{d}$, six were taking $40 \mathrm{mg} / \mathrm{d}$ and fifteen were unsure of their dose. Twenty-two were taking lansoprazole; six were taking $15 \mathrm{mg} /$ day, nine were taking $30 \mathrm{mg} / \mathrm{d}$ and seven were unsure of their dose. One subject was taking $40 \mathrm{mg}$ pantoprazole/d. Subjects had been on PPI for a minimum of 12 months. All subjects considered themselves to be compliant with PPI medication when asked.

Vitamin C intake ranged from $18-136 \mathrm{mg} / \mathrm{d}$. The current recommended daily allowance for vitamin $\mathrm{C}$ for adults is $60 \mathrm{mg} / \mathrm{d}$ (Carr \& Frei, 1999).

The eleven subjects exhibiting chronic inflammation were excluded from further analysis, leaving sixty-one subjects who had normal biopsies or showed chemical gastritis. Histologically chemical gastritis is recognized by foveolar hyperplasia in the absence of an inflammatory cell infiltrate (Dixon et al. 1986). As there were no statistically significant differences between these histological groups (for any of the parameters measured) the results were combined and the data subdivided by supplementation status for statistical analysis.

\section{Plasma}

The supplemented and placebo subjects were compared for levels of ascorbic acid, total vitamin $\mathrm{C}$, vitamin $\mathrm{E}$ and TAP. Ascorbic acid, total vitamin $\mathrm{C}$ and vitamin $\mathrm{E}$ were significantly higher in the supplemented subjects than their corresponding placebo subjects $(P<0 \cdot 0001$; Table 1$)$. No significant differences were found in TAP levels.

\section{Gastric juice}

The supplemented subjects showed a significantly higher level of ascorbic acid and total vitamin $\mathrm{C}$ in gastric juice than the placebo subjects $(P=0 \cdot 01$; Table 2$)$. The data for the placebo subjects were not significantly different from the control data.

\section{Tissue}

The supplemented and placebo subjects were compared for levels of ascorbic acid, total vitamin $\mathrm{C}$ (Table 3), and MDA, chemiluminescence and comet levels (Table 4). Ascorbic acid and total vitamin $\mathrm{C}$ levels were higher in the supplemented groups but this did not reach statistical significance. There were no differences in the measures of free radical species, lipid peroxidation or DNA damage.

\section{Discussion}

We selected this group of subjects so that we could assess the effect of vitamin $\mathrm{C}$ and $\mathrm{E}$ supplementation on factors that may predispose to gastric cancer without changes in gastric pathology such as chronic inflammation masking any response to the antioxidants.

The plasma results are consistent with good compliance and are comparable with previous studies from our group and others, showing supplemented values significantly higher for ascorbic acid (Waring et al. 1996), total vitamin C (Waring et al. 1996) and vitamin E (Monget et al. 1996; Bunout et al. 2000). TAP values in the supplemented group were higher than in the unsupplemented group but the difference was not statistically significant. Although vitamin $\mathrm{C}$ and $\mathrm{E}$ undoubtedly make a contribution to the measurement of TAP, the assay measures a complex mixture of antioxidants and the nature of the assay makes it uncertain as to the overall contribution of any individual antioxidant within this mixture.

The results for antral tissue in the placebo group were comparable with previous findings for normal tissue for chemiluminescence (Drake et al. 1998) and comet (Everett et al. 1996) and indicate a lack of elevation in free radicals in the tissue. Such findings are very different from inflamed mucosa taken from patients with $H$. pylori associated gastritis where there is known to be significant free radical generation (Drake et al. 1996; Everett et al. 1996). The MDA results were higher than expected for non-inflamed

Table 1. Concentrations of ascorbic acid and total vitamin C, vitamin E and total antioxidant potential (TAP) in plasma for supplemented and placebo subjects†

(Median values and interquartile ranges)

\begin{tabular}{|c|c|c|c|c|c|c|c|c|}
\hline \multirow[b]{2}{*}{ Subjects... } & \multicolumn{2}{|c|}{ Ascorbic acid $(\mu \mathrm{mol} / \mathrm{l})$} & \multicolumn{2}{|c|}{ Vitamin C ( $\mu \mathrm{mol} / \mathrm{l})$} & \multicolumn{2}{|c|}{ Vitamin $E(\mu \mathrm{mol} / \mathrm{l})$} & \multicolumn{2}{|c|}{$\begin{array}{l}\text { TAP ( } \mu \text { moles Trolox } \\
\text { equivalents/l) }\end{array}$} \\
\hline & Supplemented & Placebo & Supplemented & Placebo & Supplemented & Placebo & Supplemented & Placebo \\
\hline$n$ & 30 & 31 & 30 & 31 & 29 & 31 & 30 & 31 \\
\hline Median & 85 & 50 & $93^{*}$ & 56 & $48^{*}$ & 32 & 365 & 356 \\
\hline Interquartile range & $77-111$ & $27-68$ & $81-117$ & $28-72$ & $41-52$ & $28-37$ & $308-453$ & $269-410$ \\
\hline
\end{tabular}

* Median value was significantly different from that of corresponding placebo subjects, $P<0.0001$.

†For details of subjects and procedures, see p. 266. 
Table 2. Concentrations of ascorbic acid and total vitamin $C$ in gastric juice for supplemented and placebo subjects

(Median values and interquartile ranges)

\begin{tabular}{|c|c|c|c|c|c|c|}
\hline \multirow[b]{2}{*}{ Subjects } & \multicolumn{3}{|c|}{ Gastric juice ascorbic acid $(\mu \mathrm{mol} / \mathrm{l})$} & \multicolumn{3}{|c|}{ Gastric juice total vitamin $C(\mu \mathrm{mol} / \mathrm{l})$} \\
\hline & $n$ & Median & Interquartile range & $n$ & Median & Interquartile range \\
\hline Supplemented & 22 & $189^{*}$ & $126-255$ & 24 & $243^{*}$ & $154-329$ \\
\hline Placebo & 23 & 113 & $62-140$ & 25 & 146 & $88-225$ \\
\hline $\mathrm{pH}<4$ & 23 & $159 \dagger$ & $104-256$ & 24 & $192 \dagger$ & $132-295$ \\
\hline $\mathrm{pH}>4$ & 22 & 123 & $60-192$ & 25 & 173 & $88-248$ \\
\hline Controls§ & 53 & $101 \ddagger$ & $52-162$ & 55 & $124 \ddagger$ & $72-202$ \\
\hline
\end{tabular}

${ }^{*}$ Median value was significantly different from that of corresponding placebo subjects, $P=0.01$.

† Median value was not significantly different from corresponding value for $\mathrm{pH}>4 P=0.15$ for ascorbic acid and $P=0.26$ for total vitamin C.

$\ddagger$ Median value was not significantly different from that of corresponding placebo subjects.

$\$$ Controls were Helicobacter pylori negative subjects with normal gastric mucosa and on no acid suppression; data are from two trials previously run in the author's unit (Everett et al. 2001, 2002).

q For details of subjects and procedures, see p. 266.

mucosa and were closer to levels previously found in the mucosa of H. pylori-positive subjects (Drake et al. 1998), which suggests a possible change in the absolute quantitative values obtained with the technique. However, a qualitative comparison between the supplemented and unsupplemented values still proves to be informative. This method of measurement of MDA does have limitations as outlined by Everett et al. (2002). It measures MDA and other aldehydes produced from lipid peroxidation as well as compounds such as bilirubin, sugars and amino acids, which can also be reactive to TBA. This may well explain the upward drift in results. The corpus tissue ascorbate values are all reduced in comparison with earlier results. This could be due to a 'dilutional' effect produced by PPI therapy as it has been shown that hypertrophy of the parietal cells in the corpus occurs during treatment with both omeprazole and lansoprazole (Stolte et al. 2000).

Gastric juice concentrations for ascorbic acid and total vitamin $\mathrm{C}$ have proved to be most interesting and unexpected. It has been well documented that in hypochlorhydria there is elevated gastric juice nitrite (Sobala et al. 1991; Mowat et al. 1999), decreased gastric juice ascorbate (O'Connor et al. 1989; Schorah et al. 1991; Sobala et al. 1991; Mowat et al. 1999) and gastric bacterial overgrowth (Stockbruegger, 1985), all acknowledged risk factors for gastric cancer (Correa,1983, 1988; Waring et al. 1996).
All our subjects were on long term PPI and would be expected to exhibit increased $\mathrm{pH}$ and decreased juice ascorbate but this has not been the case. The $\mathrm{pH}$ was $>4$ in twenty-five subjects (thirteen unsupplemented and twelve supplemented) and $<4$ in twenty-four subjects (twelve unsupplemented and twelve supplemented). This variation in $\mathrm{pH}$ may be indicative of time of dose of PPI, i.e. either 6 or $16 \mathrm{~h}$ before endoscopy. The gastric juice ascorbic acid and total vitamin $\mathrm{C}$ were not significantly different between these two $\mathrm{pH}$ groups (Table 2) or from subjects in previous studies with normal gastric histology (Table 2). It would appear from these findings that $\mathrm{pH}$ in itself is not a determinant of gastric juice ascorbic acid concentration and that long term use of PPI alone does not seriously affect ascorbic acid metabolism in the stomach. This agrees with some earlier findings where changing $\mathrm{pH}$ alone in gastric juice did not affect the stability of ascorbate (Schorah, 1990). This conclusion may have been strengthened by using matched controls from subjects with normal histology and not taking PPI. However, this would mean control subjects undergoing an additional endoscopy, not required on clinical grounds. This was considered to be unjustifiable in view of the fact that an endoscopy, whilst considered minimally invasive, still has a risk factor and this research group has comparable data from several studies to draw on.

In other PPI studies patients have also had some

Table 3. Concentrations of ascorbic acid $(\mu \mathrm{mol} / \mathrm{kg})$ and total vitamin $\mathrm{C}(\mu \mathrm{mol} / \mathrm{kg})$ in antrum and corpus tissue for supplemented and placebo subjects†

(Median values and interquartile ranges)

\begin{tabular}{|c|c|c|c|c|c|c|c|c|}
\hline \multirow[b]{3}{*}{ Subjects... } & \multicolumn{4}{|c|}{ Antrum } & \multicolumn{4}{|c|}{ Corpus } \\
\hline & \multicolumn{2}{|c|}{ Ascorbic acid } & \multicolumn{2}{|c|}{ Vitamin C } & \multicolumn{2}{|c|}{ Ascorbic acid } & \multicolumn{2}{|c|}{ Vitamin C } \\
\hline & Supplemented & Placebo & Supplemented & Placebo & Supplemented & Placebo & Supplemented & Placebo \\
\hline$n$ & 30 & 31 & 29 & 31 & 26 & 23 & 25 & 23 \\
\hline Median & $717^{*}$ & 654 & $771^{*}$ & 742 & $455^{*}$ & 341 & $487^{*}$ & 392 \\
\hline Interquartile range & $488-960$ & $455-920$ & $548-965$ & $518-965$ & $345-525$ & $280-478$ & $413-519$ & $310-522$ \\
\hline
\end{tabular}

* Median value was not significantly different from that of corresponding placebo subjects.

†For details of subjects and procedures, see p. 267. 
Table 4. Antral tissue malondialdehyde, chemiluminescence and comet assay determinations for supplemented and placebo subjects†

(Median values and interquartile ranges)

\begin{tabular}{|c|c|c|c|c|c|c|}
\hline \multirow[b]{2}{*}{ Subjects... } & \multicolumn{2}{|c|}{$\begin{array}{l}\text { Malondialdehyde ( } \mu \mathrm{mol} \\
\text { TBARS } / \mathrm{kg} \text { wet weight of tissue) }\end{array}$} & \multicolumn{2}{|c|}{$\begin{array}{l}\text { Chemiluminescence } \\
\text { (counts/min per } \mathrm{mg} \text { wet } \\
\text { weight of tissue) }\end{array}$} & \multicolumn{2}{|c|}{ Comet ( $\%$ of cells) } \\
\hline & Supplemented & Placebo & Supplemented & Placebo & Supplemented & Placebo \\
\hline$n$ & 30 & 30 & 24 & 22 & 23 & 26 \\
\hline Median & $100 \cdot 7^{\star}$ & $108 \cdot 9$ & $269 \cdot 8^{*}$ & $300 \cdot 8$ & $68^{*}$ & 67 \\
\hline Interquartile range & $83.7-120.5$ & $92 \cdot 3-133 \cdot 4$ & $84 \cdot 1-542 \cdot 5$ & $74 \cdot 8-935$ & $64-76$ & $58-73$ \\
\hline
\end{tabular}

TBARS, thiobarbituric acid-related species.

* Median value was not significantly different from that of the corresponding placebo group.

†For details of subjects and procedures, see p. 266.

inflammatory response usually caused by $H$. pylori infection. This suggests that the decreased ascorbate in gastric juice previously documented in PPI treatment (Schorah, 1990; Schorah et al. 1991) is solely a consequence of chronic gastritis, either with or without $H$. pylori infection (Hayat et al. 1998), and probably reflects the generation of free radicals capable of rapidly oxidizing ascorbate to dehydroascorbic acid. When this happens in gastric juice emerging from the glands and gastric pits, the dehydroascorbic acid generated is either rapidly reabsorbed into mucosal cells and reduced to ascorbic acid again, thus maintaining the ascorbic acid concentration in the mucosa, or it escapes into the luminal gastric juice, where it is unstable and leads to the low levels of both ascorbic acid and total vitamin $\mathrm{C}$ found there (Schorah, 1997). Our conclusion that $H$. pylori related gastritis is the factor which determines gastric juice ascorbic acid and total vitamin $\mathrm{C}$ is supported by a recent study in which a reduction was only observed in $H$. pylori positive patients (Mowat et al. 2000).

Simple inhibition of the proton pump, as in subjects in the present study, without accompanying free radical generation does not increase production of dehydroascorbic acid, and does not reduce gastric juice vitamin C. Our findings have shown that in this group of $H$. pylori negative subjects there are neither the changes in ascorbate metabolism nor the generation of potential carcinogens or DNA damage that have been demonstrated in $H$. pylori positive gastritis. Thus the PPI treated patient does not represent a good 'model' for studying the effects of reduced ascorbate levels on carcinogenicity as was originally thought. As a consequence of this, we cannot address our original hypothesis. We have found that supplementation of vitamin $\mathrm{C}$ and $\mathrm{E}$ does not affect DNA damage in this group of patients. This group also appear to have a balanced diet and were generally not deficient in vitamin $\mathrm{C}$ intake, which implies that any positive effect gained by vitamin supplementation may only be detected in a deficient group. We would also predict from these findings that, in the absence of $H$. pylori infection and a gastric inflammatory cell response, inhibition of the proton pump does not increase the risk of gastric cancer. However, PPI therapy is a relatively new regimen in the context of gastric carcinogenesis and a full assessment of its action will not be available for a considerable time.

\section{Acknowledgements}

The study was sponsored by a grant from the World Cancer Research Fund. (Grant no. 97A16). Thanks to Professor C. P. Wild and Dr J. M. Allan, Molecular Epidemiology Unit, for valuable help with the preparation of the manuscript, to Dr D. C. Greenwood, Academic Unit of Epidemiology and Health Services Research, for advice on statistical analysis and also to Jill Laws, Andrea Scales, Julie Mackintosh and the endoscopy nurses, The General Infirmary at Leeds.

\section{References}

Bunout D, Garrido A, Suazo M, Kauffman R, Venegas P, de la Maza P, Petermann M \& Hirsch S (2000) Effects of supplementation with folic acid and antioxidant vitamins on homocysteine levels and LDL oxidation in coronary patients. Nutrition 16, 107-110.

Carr AC \& Frei B (1999) Toward a new recommended dietary allowance for vitamin $\mathrm{C}$ based on antioxidant and health effects in humans. American Journal of Clinical Nutrition 69, 1086-1107.

Correa P (1983) The precancerous process. Cancer Survey 2 , 437-450.

Correa P (1988) A human model of gastric carcinogenesis. Cancer Research 48, 3554-3565.

Correa P (1992) Human gastric carcinogenesis: a multistep and multifactoral process. Cancer Research 52, 6735-6740.

Davies GR, Simmonds NJ, Stevens TRJ, Grandison A, Blake DR \& Rampton DS (1992) Mucosal reactive oxygen metabolite production in duodenal ulcer disease. Gut 33, 1467-1472.

Dixon MF, O'Connor H, Axon ATR, King RFJG \& Johnston D (1986) Reflux gastritis: distinct histopathological entity? Journal of Clinical Pathology 39, 524-530.

Dizdaroglu M (1993) Chemistry of free radical damage to DNA. In DNA and Free Radicals, pp. 19-39 [B Halliwell and OI Arunoma, editors]. Chichester: Ellis Horwood.

Drake IM, Davies MJ, Mapstone NP, Dixon MF, Schorah CJ, White KLM, Chalmers DM \& Axon ATR (1996) Ascorbic acid may protect against human gastric cancer by scavenging mucosal oxygen radicals. Carcinogenesis 17, 559-562.

Drake IM, Mapstone NP, Schorah CJ, White KLM, Chalmers DM, Dixon MF \& Axon ATR (1998) Reactive oxygen species activity and lipid peroxidation in Helicobacter pylori associated gastritis: Relation to gastric mucosal ascorbic acid concentrations and the effect of H. pylori eradication. Gut $\mathbf{4 2}$, $768-771$. 
Drake IM, Warland D, Carswell N, Schorah CJ, Mapstone N, Axon ATR, Chalmers DM, Dixon MF \& White KLM (1995) Reactive oxygen species (ROS) activity and damage in Helicobacter pylori associated gastritis: effect of eradication therapy. Gut 35, Suppl., 10.

Everett SM, Drake IM, White KLM, Mapstone NP, Chalmers DM, Schorah CJ \& Axon ATR (2002) Antioxidant vitamin supplements do not reduce the reactive oxygen species activity in Helicobacter pylori gastritis in the short term. British Journal of Nutrition 87, 3-11.

Everett SM, Singh R, Leuratti C, White KLM, Neville P, Greenwood D, Marnett LJ, Schorah CJ, Forman D, Shuker D \& Axon ATR (2001) Levels of malondialdehyde-deoxyganosine in the gastric mucosa - relationship with lipid peroxidation, ascorbic acid and Helicobacter pylori. Cancer Epidemiology, Biomarkers and prevention 10, 369-376.

Everett SM, White K, Calvert R, Drake IM, Skinner C, Miller D, Schorah CJ \& Axon ATR (1996) The measurement of DNA single strand breaks, using the 'COMET' assay, in Helicobacter pylori associated gastritis. Gut 38, Suppl., A2.

Everett SM, White KLM, Schorah CJ, Calvert RJ, Skinner C, Miller D \& Axon ATR (2000) In vivo DNA damage in gastric epithelial cells. Mutation Research 468, 73-85.

Fang JL, Vaca CE, Valstra LM \& Mutamen M (1996) Determination of DNA adducts of malondialdehyde in humans; effects of dietary fatty acid composition. Carcinogenesis 17, $1035-1040$.

Guyton KZ \& Kensler TN (1993) Oxidative mechanisms in carcinogenesis. British Medical Bulletin 49, 523-544.

Halliwell B (1994) Free radicals, antioxidants and human disease. Lancet 344, 721-724.

Hayat M, Everett SM, White KLM, Drake IM \& O'Mahony S (1998) Ascorbic acid and total vitamin C concentrations in plasma, gastric juice, and gastrointestinal mucosa in lymphocytic gastritis. Gastroenterology 114, A146.

Kyrtopoulos SA (1989) N-nitroso compound formation in human gastric juice. Cancer Surveys 8, 423-442.

Lunec J (1990) Free radicals: their involvement in disease processes. Annals of Clinical Biochemistry 27, 173-182.

Monget AL, Richard MJ, Cournot MP, Arnaud J, Galan P, Preziosi P, Herbeth B, Favier A \& Hereberg S (1996) Effect of 6 month supplementation with different combinations of an association of antioxidant nutrients on biochemical parameters and markers of the antioxidant defence system in the elderly. The Geriatrie/Min. Vit. Axon Network. European Journal of Clinical Nutrition 50, 443-449.

Mowat C, Carswell A, Wirz A \& McColl KEL (1999) Omeprazole and dietary nitrate independently affect levels of vitamin $\mathrm{C}$ and nitrite in gastric juice. Gastroenterology 116, 813-822.

Mowat C, Williams C, Gillen D, Hossack M, Gilmour D, Carswell A, Wirz A, Preston T \& McColl KEL (2000) Omeprazole, Helicobacter pylori status, and alterations in the intragastric milieu facilitating bacterial N-nitrosation. Gastroenterology 119, 339-347.

O'Connor HJ, Schorah CJ, Habibzedah N, Axon ATR \& Cockel $\mathrm{R}$ (1989) Vitamin $\mathrm{C}$ in the human stomach; relation to gastric
$\mathrm{pH}$, gastroduodenal disease and possible sources. Gut 30, 436-442.

Sanderson MJ, White KLM, Drake IM \& Schorah CJ (1997) Vitamin $\mathrm{E}$ and carotenoids in gastric biopsies: the relation to plasma concentrations in patients with and without Helicobacter pylori gastritis. American Journal of Clinical Nutrition $\mathbf{6 5}$, $101-106$.

Schorah CJ (1990) Gastric juice ascorbic acid; Effects of disease, hypochlorhydria and stimulation of gastric secretion. Proceedings of the Nutrition Society 49, 31A.

Schorah CJ (1995) Micronutrients, antioxidants and risk of cancer. Bibliotheca Nutritio Dieta 52, 92-107.

Schorah CJ (1997) Ascorbic acid metabolism in the human stomach. Acta Gastro-Enterologica Belgica 60, 217-219.

Schorah CJ, Sobala GM, Sanderson M, Collis N \& Primrose JN (1991) Gastric juice ascorbic acid: effect of disease and implications for gastric carcinogenesis. American Journal of Clinical Nutrition 53, 287s-293s.

Singh NP, McCoy MT, Tire RR \& Schnieder EL (1988) A simple technique for quantification of low levels of DNA damage in individual cells. Experimental Cell Research 5, 184-191.

Sobala GM, Pignatelli B, Schorah CJ, Bartsh H, Sanderson M, Dixon MF, Shires S, King RFJG \& Axon ATR (1991) Levels of nitrite, nitrate, N-nitroso compounds, ascorbic acid and total bile acids in gastric juice of patients with and without precancerous conditions of the stomach. Carcinogenesis 12, $193-198$.

Sobala GM, Schorah CJ, Sanderson M, Dixon MF, Tomkins DS, Godwin P \& Axon ATR (1989) Ascorbic acid in the human stomach. Gastroenterology 97, 357-363.

Sobala GM, Schorah CJ, Shires S, Lynch DAF, Gallacher B, Dixon MF \& Axon ATR (1993) Effect of eradication of Helicobacter pylori on gastric juice ascorbic acid concentrations. Gut 34, 1038-1041.

Stockbruegger RW (1985) Bacterial overgrowth as a consequence of reduced gastric acidity. Scandinavian Journal of Gastroenterology 111, Suppl., 7-16.

Stolte M, Meining A, Seifert E \& Alexandridis T (2000) Treatment with lansoprazole also induces hypertrophy of the parietal cells of the stomach. Pathology, Research and Practice 196, $9-13$.

Thurnham DI, Smith E \& Fiora PS (1988) Concurrent liquid chromatographic assay of retinal, $\alpha$-tocopherol, $\beta$-carotene, $\alpha$-carotene, lycopene and $\beta$-cryptoxanthin in plasma, with tocopherol acetate as internal standard. Clinical Chemistry 34, $377-381$.

Waring AJ, Drake IM, Schorah CJ, White KLM, Lynch DAF, Axon ATR \& Dixon MF (1996) Ascorbic acid and total vitamin $\mathrm{C}$ concentration in plasma, gastric juice and gastric intestinal mucosa; effects of gastritis and oral supplementation. Gut 38, 171-176.

Whitehead TP, Thorpe GHG \& Maxwell SRJ (1992) Enhanced chemiluminescence assay for antioxidant capacity in biological fluids. Analytica Chimica Acta 266, 265-277.

Yagi K (1976) A simple fluorometric assay for lipoperoxide in blood plasma. Biochemical Medicine 15, 212-216. 